\title{
Antioxidants and Anti-inflammatory Effects of Fermented Houttuynia cordata Thunb and Scoria Mixture Extract
}

\author{
Sung-Gyu Lee ${ }^{1}$, Sangmoon Kang ${ }^{2}$, Kee-Young Lee ${ }^{2}$, Kwang-Lyul Park ${ }^{3}$ and Hyun Kang ${ }^{1, \dagger}$ \\ ${ }^{I}$ Department of Medical Laboratory Science, College of Health Science, \\ Dankook University, Chungnam 31116, Korea \\ ${ }^{2}$ Department of A\&PEP, Rearch Institute, Chungbuk, 363-883, Korea \\ ${ }^{3}$ Scoria Industry Co., LTD, Jeju-city, 63018, Korea
}

In this study, antioxidant and anti-inflammatory of fermented Houttuynia cordata Thunb and scoria mixture extract were investigated in vitro. Radical-scavenging activities of the ethanol extracts were examined by using $\alpha, \alpha$-diphenyl- $\beta$ picrylhydrazyl (DPPH) and 2,2-azino-bis(3-ethylbenzthiazoline-6-sulfonic acid (ABTS)) radicals assay. Consequently, we confirmed that fermented Houttuynia cordata Thunb and scoria mixture extract dependent removed DPPH and ABTS radical. Also, to confirm anti-inflammatory activity of ethanol extract, we treated fermented Houttuynia cordata Thunb and scoria mixture extract on BV-2 cell with LPS. The result showed that fermented Houttuynia cordata Thunb and scoria mixture extract concentration-dependent inhibited NO production. Therefore, fermented Houttuynia cordata Thunb and scoria mixture extract showed inhibition radical oxygen activities and inflammatory and have available for a pharmacological composition on neuritis-protection and treatment.

Key Words: Antioxidant, Anti-inflammatory, Scoria, Fermentation, Houttuynia cordata

\section{서 론}

최근 기능성 천연 소재에서 발효기술을 접목한 소재들 에 대한 관심이 증가하고 있다. 발효된 소재들은 에너지 원을 제외한 영양 성분들은 대부분 그대로 보존되고 생 리활성 배당체 성분들을 비배당체로 전환하여 생리활성 물질의 체내 흡수율을 증대시킬 수 있는 이점을 가지고 있다(Bae et al., 2004). 한편, 인간의 수명이 연장되면서 만 성질환인 생활습관병(lifestyle related disease)이 급증하고 있는데(Tanaka et al., 2000), 이러한 원인은 생체의 대사과 정에서 발생되는 활성산소류(reactive oxygen species, ROS) 에 기인한다고 알려졌다(Wiseman, 1996; Bouayed and Bohn,
2010). ROS는 세포 내 DNA, RNA, 단백질 등과 반응하여 세포 손상 및 파괴 등을 유발하여(Aischer and Hess, 1993; Chen et al., 2012) 암, 동맥경화, 당뇨병과 같은 다양한 질 병과 노화를 이끌고 특히 다른 장기에 비해 산소의 이용 율이 높은 뇌의 경우, 신경세포의 사멸을 유도하여 알츠 하이머병, 파킨슨병, 간질, 뇌졸중 등과 같은 질환을 유발 시킨다(Decker et al., 1992).

이러한 활성산소는 체내에서 존재하는 Superoxide dismutase (SOD), glutathione peroxidase (GPX), catalase (CAT), glutathione reductase, glutathione-S-transferase과 같은 항산화 효소들로 인하여 자연적으로 없어지긴 하지만, 대사과정 에 있어 문제가 발생되거나 염증과 관련된 인체질환이 야 기된다면, 체내에 존재하는 항산화 물질이 고갈되어 효과

* Received: September 1, 2017 / Revised: September 20, 2017 / Accepted: September 26, 2017

†Corresponding author: Hyun Kang. Department of Medical Laboratory Science, College of Health Science, Dankook University, Cheonan-si, Chungnam 31116, Korea.

Tel: +82-41-550-3015, Fax:+82-41-559-7934, e-mail: hkang@dankook.ac.kr

(C) The Korean Society for Biomedical Laboratory Sciences. All rights reserved.

(C) This is an Open Access article distributed under the terms of the Creative Commons Attribution Non-Commercial License (http://creativecommons.org/licenses/by-nc/3.0/) which permits unrestricted non-commercial use, distribution, and reproduction in any medium, provided the original work is properly cited. 


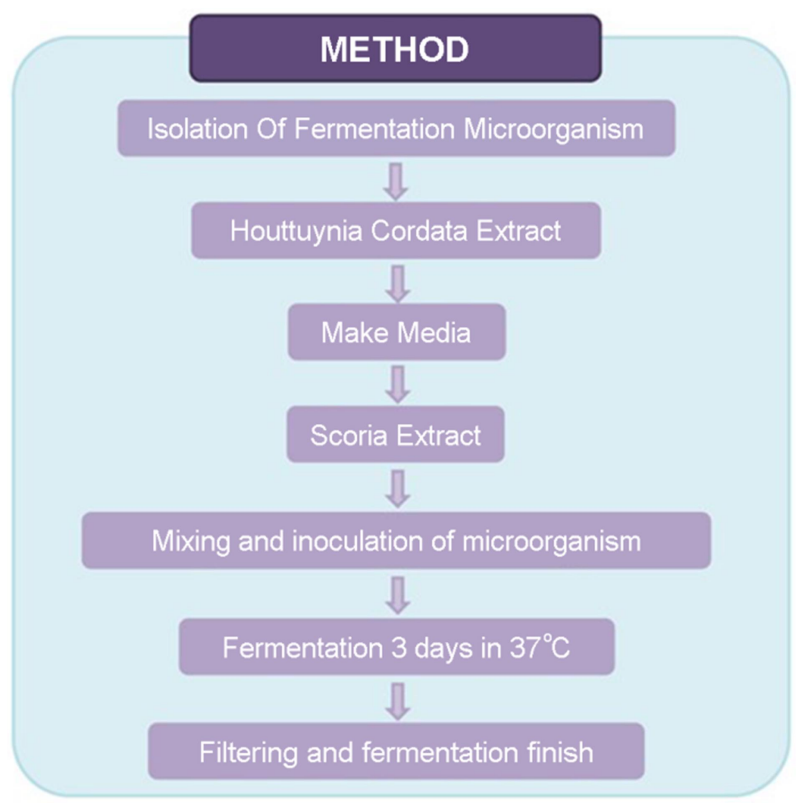

Fig. 1. Schematic diagram for preparation of fermented Houttuynia cordata (FHC) and fermented Houttuynia cordata-scoria (FHC-S).

적으로 ROS를 제거하는데 실패할 수 있기 때문에 외부로 부터 항산화 물질을 섭취할 필요가 있다(Wiseman, 1996; Bouayed and Bohn, 2010; Aischer and Hess, 1993).

어성초(Houttuynia cordata)는 삼백초과(Saururaceae)에 속 하는 다년생 초본의 야생 약초로서 본의 야생 약초로서 우리나라, 중국, 일본 등지에서 자생하고 있다(Jang et al., 1999). 지역에 따라 약간의 차이는 있으나, 보통 4 월경에 싹이 트고, 6 8월경에 꽃이 피며, 특유의 독특한 냄새(비 린내)를 함유한 생리활성 물질들이 있다. 어성초의 생리 활성 성분은 플라보노이드 유도체인 quercetin, quercitrin, isoquercitrin, reynoutrin, hyperin, rutin 등과 정유 성분으로 decanoyl acetaldehyde, methyl nonylketone, laurinaldehyde, myrcene 등이 함유되어 있으며(Hong and Kim, 2004), 효능 에 관한 연구로는 항균(Song et al., 2003), 항산화(Lee et al., 1993), 항백혈병 및 고지혈증 억제 효과(Chung et al., 1999), 신경세포 보호작용(Jeong et al., 2010) 등이 보고되고 있다.

제주 화산송이는 제주도 일원의 110 회 화산이 폭발할 때 분출된 여러 물질 가운데 다공질의 화산암, 화산 모래, 기타 화산회 등이 혼합되어 고열에서 소성된 소성체로 이루어진 기공률이 높은 화산토를 일컬으며, 우리나라 제 주도에만 있는 세계 유일의 인체혈액과 유사한 약알칼리 성 자원으로, 제주도 방언으로 '송이(Scoria)'라 불린다. 송
이는 기생화산(오름)으로 생성되어 제주 전역에 거쳐 분 포되어 있으며, 색상에 있어서 적갈색, 황갈색, 검정색 및 암회색의 색상으로 크게 구분되고, 가장 일반적으로 적갈 색을 띄는 송이가 가장 많이 분포되어 있다. 예로부터 고 온 다습한 환경인 제주도에서는 화산석 송이를 이용하여 가옥의 지붕, 내외 벽에 사용하여 보온, 단열, 방음, 방습 제로 사용하였고, 마당 도로에 깔아 복사열 방지는 물론, 우천 시 훍탕물 방지와 여과제로 널리 이용되어 왔으며, 최근에는 토양 개량제, 비료 첨가제, 사료 첨가제, 천연염 색제, 화장품 원료 등으로 개발되고 있다. 특히 항균, 항염, 보습 효과와 같은 효능들이 있지만 이에 대한 체계적인 연구가 부족한 실정이다.

따라서 본 연구에서는 어성초 발효액과 화산송이 복합 발효액의 항산화 및 항염 효과를 조사하여 새로운 기능성 식품 및 화장품 소재가 될 수 있는지를 검토해 보았으며, 화산송이에 의한 활성의 차이도 확인해 보았다.

\section{재료 및 방법}

\section{어성초 및 화산송이 복합 발효액 제조}

어성초는 경동시장에서 구입하여 $20 \mathrm{mesh}$ 이하로 조분 쇄하여 시료 $100 \mathrm{~g}$ 에 대해 100 배의 $70 \%$ 에탄올을 넣어 72시간 동안 추출한 후, 여과(Whatman No 2, Maidstone, England)하였다. 여과한 에탄올 추출액을 감압농축 $(\mathrm{N}-$ 1000S-WD, Eyela Co., Tokyo, Japan) 후 동결건조(FDU-1100, Eyela Co., Tokyo, Japan)하여 에탄올 추출물을 제조하였다.

본 연구에 사용된 발효 미생물은 Apep Microorganism Jeju 170201 로 에이앤펩에서 분리 동정한 미생물로 학명은 Bacillus subtilis 이다. 전배양은 nutrient broth (Difco, Detroit, $\mathrm{MI}, \mathrm{USA}), 37^{\circ} \mathrm{C}$ 진탕 배양기에서 24 시간 배양하였다. 발효 에 사용된 화산송이는 (주)송이산업의 화산송이를 받아 진 행하였다. 발효 시 사용된 조성은 어성초 추출물 $5 \%$, 화 산송이 $0.5 \%$, glucose $0.6 \%$, yeast extract $0.3 \%$, soytone $0.1 \%$ 로 진행하였다. 발효 조성에 Bacillus subtilis를 접종하여 $37^{\circ} \mathrm{C}$ 에서 3 일간 진탕 배양하여 발효를 진행하였다. 발효 완료 후 발효물은 $0.2 \mu \mathrm{m}$ 필터를 이용하여 여과하였다 (Fig. 1).

\section{총 폴리페놀 함량 측정}

어성초 및 화산송이 복합 발효물의 총 폴리페놀 화합물 의 함량 비교를 위해 Folin-Denis법(Folin and Denis, 1912) 을 응용하였다. 각 발효액을 농도별로 희석한 용액 $2 \mathrm{~mL}$ 
에 2배 희석된 Folin 시약(Sigma Co., St. Louis, MO, USA) $2 \mathrm{~mL}$ 을 첨가하여 잘 혼합하였다. 혼합액을 3 분간 방치한 다음 $10 \% \mathrm{Na}_{2} \mathrm{CO}_{3}$ (Sigma Co., St. Louis, MO, USA) $2 \mathrm{~mL}$ 을 넣고 1 시간 반응시킨 후 UV/Visible spectrophotometer (UVIKON 922, Kontran Co., Milan, Italy) $700 \mathrm{~nm}$ 에서 흡광도 를 측정하여 작성한 표준곡선으로부터 함량을 구하였다. 이 때 gallic acid (Sigma Co., St. Louis, MO, USA)를 이용한 표준곡선은 gallic acid의 최종농도가 $0,5,25,50,75 \mu \mathrm{g} / \mathrm{mL}$ 가 되도록 하여 위와 같은 방법으로 $700 \mathrm{~nm}$ 에서 흡광도 를 측정하여 구하였다.

\section{총 플라보노이드 함량 측정}

어성초 및 화산송이 복합 발효액의 총 플라보노이드 함 량은 Nieva Moreno 등(Nieva et al., 2000)의 방법을 응용하 여 측정하였다. 각 샘플 $0.1 \mathrm{~mL}$ 와 $80 \%$ 에탄올 $0.9 \mathrm{~mL}$ 을 혼합한 혼합물 $0.5 \mathrm{~mL}$ 에 $10 \%$ aluminium nitrate (Sigma Co., St. Louis, MO, USA)와 1 M potassium acetate (Sigma Co., St. Louis, MO, USA) $0.1 \mathrm{~mL}$ 그리고 $80 \%$ 에탄올 $4.3 \mathrm{~mL}$ 을 가 하여 실온에 40 분 방치한 뒤 $415 \mathrm{~nm}$ 에서 흡광도를 측정 하였다. 이때 총 플라보노이드 함량은 quercetin (Sigma Co., St. Louis, MO, USA)을 이용하여 작성한 표준곡선으로부터 함량을 구하였다.

\section{1,1-diphenyl-2-picryl hydrazyl (DPPH) radical 소거 활성 측정}

어성초 및 화산송이 복합 발효물의 free radical 소거활 성은 stable radical인 DPPH (Sigma Co., St. Louis, MO, USA) 에 대한 환원력을 측정한 것으로 $99 \%$ 메탄올에 각 시 료를 희석한 희석액 $800 \mu \mathrm{L}$ 와 메탄올에 녹인 $0.15 \mathrm{mM}$ $\mathrm{DPPH}$ 용액 $200 \mu \mathrm{L}$ 를 가하여 실온에 30 분 방치한 후 517 $\mathrm{nm}$ 에서 흡광도를 측정하였다. DPPH radical 소거활성은 다 음 식에 따라 소거활성을 계산하였다.

DPPH radical scavenging activity $(\%)=[100-(\mathrm{S} / \mathrm{C} \times 100)]$

$\mathrm{S}$ : 시료군 반응 후 흡광도 - 시료군 반응 전 흡광도

$\mathrm{C}$ : 대조군 반응 후 흡광도 - 대조군 반응 전 흡광도

\section{2,2-azino-bis(3-ethylbenzthiazoline-6-sulfonic acid (ABTS)) radical 소거활성}

ABTS radical을 이용한 항산화력 측정은 $\mathrm{ABTS}+\cdot$ cation decolorization assay 방법(Re et al., 1999)에 의하여 시행하였 다. $7 \mathrm{mM}$ ABTS (Sigma Co., St. Louis, MO, USA)와 $2.45 \mathrm{mM}$ potassium persulfate (Sigma Co., St. Louis, MO, USA)를 최 종농도로 혼합하여 실온인 암소에서 24시간 동안 방치하 여 $\mathrm{ABTS}+$ 을 형성시킨 후 $732 \mathrm{~nm}$ 에서 흡광도 값이 0.70 $( \pm 0.02)$ 이 되게 phosphate buffered saline (PBS, $\mathrm{pH}$ 7.4)로 희 석하였다. 희석된 용액 $990 \mu \mathrm{L}$ 에 sample $10 \mu \mathrm{L}$ 를 가하여 정확히 1 분 동안 방치한 후 흡광도를 측정하였다.

\section{세포주 배양}

본 실험에 사용된 microglia cell line BV-2 세포는 미국 하버드대학교에서 분양받아 사용하였다. BV-2 세포는 $10 \%$ fetal bovine serum (FBS; Gibco, BRL, USA), $100 \mu \mathrm{g} / \mathrm{mL}$ penicillin (Gibco, BRL, USA) 그리고 $100 \mu \mathrm{g} / \mathrm{mL}$ streptomycin (Gibco, BRL, USA)을 첨가한 RPMI1640 배지(Gibco, BRL, $\mathrm{USA}$ )를 이용하여 $5 \% \mathrm{CO}_{2}$ 가 존재하는 $37^{\circ} \mathrm{C}$ 배양기에서 2 3일에 한 번씩 계대 배양하였다.

\section{세포 생존율 측정}

LPS로 자극된 BV-2 세포에서 LPS 및 모시풀 추출물이 세포 생존에 미치는 영향을 확인하기 위해 cell viability를 3-[4,5-Dimethylthiazol-2-yl]-2,5-diphenyl-tetrazolium bromide (MTT) 분석법으로 측정하였다. 세포 $\left(1 \times 10^{5} \mathrm{cell} / \mathrm{mL}\right)$ 를 96well plate에 $180 \mu \mathrm{L}$ 씩 분주하여 12 시간 이상 $\mathrm{CO}_{2}$ 배양기 에서 배양한 다음, 시료를 각각의 조건에 따라 처리하여 24 시간 배양하였다. 배양한 후 배양액을 제거하고 $0.5 \mathrm{mg}$ $\mathrm{mL} \mathrm{MTT}$ 가 함유되어 있는 배지 $200 \mu \mathrm{L}$ 를 첨가한 다음 4시간 동안 배양하여 MTT가 환원되도록 하였다. 그 후 배양액을 제거하고 dimethyl sulfoxide (DMSO) $100 \mu \mathrm{L}$ 첨가 하여 생성된 formazone 결정을 용해시킨 후, ELISA reader (Bio-Rad Co., USA)를 이용하여 $540 \mathrm{~nm}$ 에서 흡광도를 측 정하였다. 세포 생존율은 대조군과 비교하여 백분율(\%)로 나타내었다.

\section{LPS로 활성화된 신경교세포에서 NO 생성저해 작용}

어성초 및 화산송이 복합 발효액의 항염증 효능을 분석 하기 위하여 본 연구에서는 염증 유발 인자인 LPS를 각 농도별로 자극된 신경교세포에서 생산되는 $\mathrm{NO}$ 농도를 의 존적으로 효능을 있는지 확인하였다. $\mathrm{NO}$ 측정은 24 well plate에 세포를 $5 \times 10^{5}$ cell/을 seeding한 후, LPS와 발효물 을 농도차를 두어 첨가한 후, $24 \mathrm{~h}$ incubator에서 반응시킨 후, 각각 $50 \mu \mathrm{L}$ 씩 Griess reagent ( $1 \%$ sulfanilamide/ $0.1 \%$ $\mathrm{N}-\left(1\right.$-naphthyl)-ethylenediamine dihydrochloride $\left./ 2.5 \% \quad \mathrm{H}_{3} \mathrm{PO}_{4}\right)$ 와 반응시킨 후, 파장이 $540 \mathrm{~nm}$ 인 ELISA reader (Bio-Rad 
Table 1. Total polyphenols and flavonoids contents in fermented Houttuynia cordata (FHC) and fermented Houttuynia cordatascoria (FHC-S)

\begin{tabular}{lcc}
\hline \hline Sample & $\begin{array}{c}\text { Total polyphenols }^{1)} \\
(\mu \mathrm{g} / \mathrm{mL})\end{array}$ & $\begin{array}{c}\text { Total flavonoids }^{2)} \\
(\mu \mathrm{g} / \mathrm{mL})\end{array}$ \\
\hline FHC & $6.02 \pm 0.17^{3)}$ & $10.85 \pm 0.45$ \\
FHC-S & $3.84 \pm 0.32$ & $8.55 \pm 0.17$ \\
\hline
\end{tabular}

${ }^{1)}$ Milligrams of total polyphenol content/g of samples based on gallic acid as standard.

2) Milligrams of total flavonoid content/g of samples based on quercetin as standard.

${ }^{3)}$ Each value is mean \pm S.D. $(n=3)$.

FHC : Fermented Houttuynia cordata

FHC-S: Fermented Houttuynia cordata-scoria

Co., USA)를 사용하여 값을 측정하였다.

\section{결 과}

\section{폴리페놀 및 플라보노이드 함량 비교}

어성초 및 화산송이 복합 발효액에 존재하는 총 폴리페 놀 및 플라보노이드 함량은 각각 gallic acid, quercetin을 기 준 물질로 하여 측정하였다(Table 1). 그 결과, $\mathrm{FHC}$ (어성초 발효액)의 총 폴리페놀 함량은 $6.02 \mu \mathrm{g} / \mathrm{mL}, \mathrm{FHC}-\mathrm{S}$ (어성초 -화산송이 복합 발효액)는 $3.84 \mu \mathrm{g} / \mathrm{mL}$ 로 나타나, 화산송 이를 첨가하지 않은 발효액에서 높은 폴리페놀 함량을 보 였다. 총 플라보노이드 함량은 FHC와 FHC-S에서 각각 $10.85,8.55 \mu \mathrm{g} / \mathrm{mL}$ 로 폴리페놀 함량 경향과 유사하게 나타 났다.

\section{어성초 및 화산송이 복합 발효액의 DPPH 및 ABTS free radical 소거활성}

어성초 및 화산송이 복합 발효액의 항산화능을 측정하 기 위해 DPPH 소거활성을 농도별로 측정한 결과는 Fig. $2 \mathrm{~A}$ 와 같다. $\mathrm{FHC}$ (어성초 발효액)은 100 배, 50 배, 10 배, 5 배 각각 희석액에서 약 $0,11.5,41.5,70 \%$ 의 소거능을 보였고, 동일한 희석액에서의 FHC-S(어성초-화산송이 복합 발효 액)는 약 $100,100,88,35.5 \%$ 의 소거능을 보였다. 특히 화 산송이가 첨가되면서 어성초 단독 발효액보다 소거활성 이 높아지는 것을 확인할 수 있었다. ABTS+· 소거활성 역시 DPPH 소거활성과 유사하게 화산송이를 첨가하여 발 효한 FHC-S에서 높은 소거활성을 나타냄을 확인하였다 (Fig. 2B).

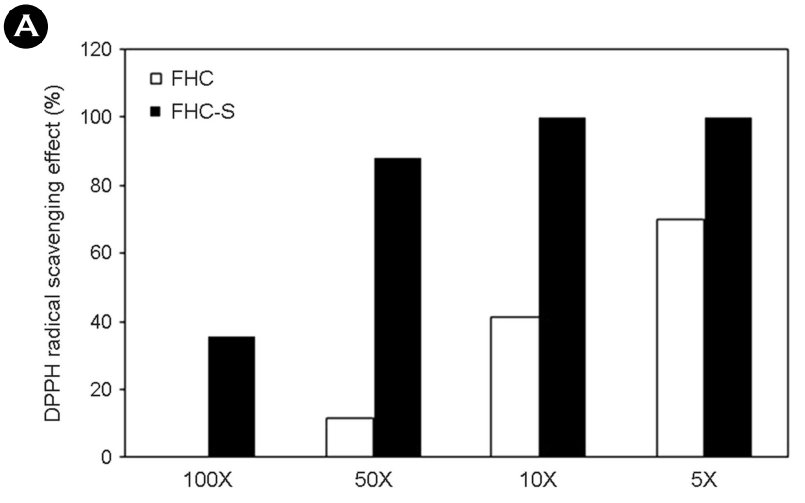

B

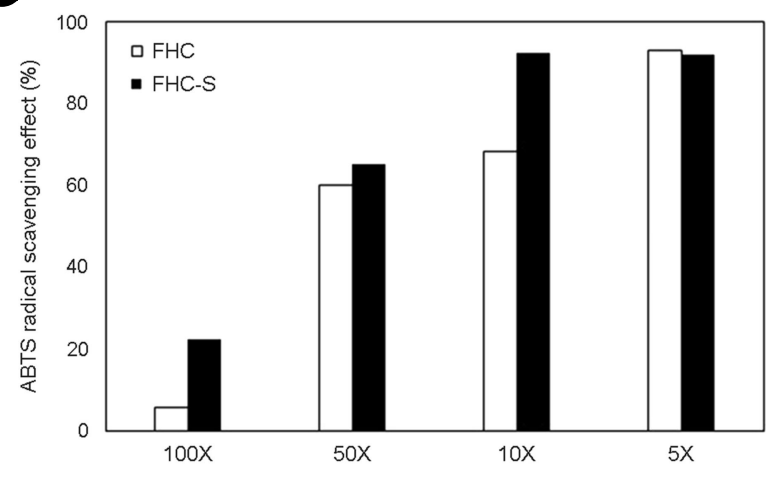

Fig. 2. DPPH (A) and ABTS (B) radical scavenging effects of fermented Houttuynia cordata (FHC) and fermented Houttuynia cordata-scoria (FHC-S). Dilution concentration: $5 \times, 10 \times, 50 \times$, $100 \times$.

\section{세포 생존율 측정}

어성초 및 화산송이 복합 발효액이 세포 생존에 끼치는 영향을 확인하기 위해 BV-2 cell에 LPS, FHC(어성초 발효 액) 그리고 FHC-S(어성초-화산송이 복합 발효액)를 농도 별로 처리하였다. 먼저, LPS $100 \mathrm{ng} / \mathrm{mL}$ 를 단독으로 처리 하였을 때, 대조군에 비교하여 큰 차이가 없었다. 또한, LPS와 FHC 혹은 FHC-S를 같이 처리하였을 때에도 cell viability가 20 200배 희석액에서는 95\% 이상으로 세포 생 존에 끼치는 영향이 없었지만 FHC-S 10 배 희석액에서는 세포에 독성을 나타내는 것을 확인하였다(Fig. 3).

\section{어성초 및 화산송이 복합 발효액의 NO 생성저해 효과}

어성초 및 화산송이 복합 발효액의 항염 효과를 확인하 기 위하여 LPS로 자극하여 염증 반응을 유도한 BV-2 cell 에 $\mathrm{FHC}$ (어성초 발효액) 그리고 $\mathrm{FHC}-\mathrm{S}$ (어성초-화산송이 복합 발효액)를 희석액별로 처리한 후, $\mathrm{NO}$ 의 생성농도를 확인하였다. 먼저 $\mathrm{FHC}$ 를 처리하였을 때, BV-2 cell에서 생 


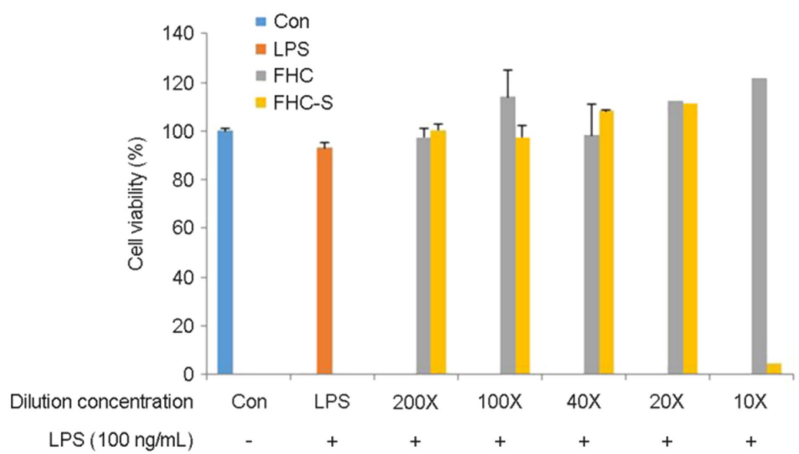

Fig. 3. Effect of fermented Houttuynia cordata (FHC) and fermented Houttuynia cordata-scoria (FHC-S) on cytotoxicity in BV-2 cells. FHC and FHC-S was treated with various concentrations in BV-2 cells for $24 \mathrm{~h}$. Values are expressed as the mean $\pm \mathrm{SD}(\mathrm{n}=3)$ of determinations made in triplicate experiments. Dilution concentration: $10 \times, 20 \times, 40 \times, 100 \times, 200 \times$

성하는 $\mathrm{NO}$ 의 농도는 40 배 희석액에서부터 증가된 $\mathrm{NO}$ 농도가 $50 \%$ 이상 감소되는 것을 확인할 수 있었다. 반면, FHC-S는 100 배 희석액에서부터 LPS control과 대조하여 $50 \%$ 이상 줄어드는 것을 확인할 수 있었다(Fig. 4).

\section{고 찰}

본 연구에서는 어성초 발효액의 항산화 및 항염 효과 를 측정하고, 더불어 화산송이 첨가로 인한 발효액의 기 능성 향상 효과를 확인하였다. 폴리페놀 화합물이나 플라 보노이드류는 여러 가지 식품에 분포되어 있으며 천연항 산화제로 작용한다는 보고가 많이 알려져 있다(Sato et al., 1996; Bors and Saran, 1987). 특히 플라보노이드류는 암세포 의 DNA, RNA 그리고 protein의 합성을 억제 또는 cAMP 의 농도를 증가시킴으로써 종양세포의 분열을 억제하거나 apoptosis를 유도하는 등의 다각적 기전을 통해 항암 효 과를 발휘하는 것으로 알려져 있다(Suolinna et al., 1975; Gerriten, 1995). 천연항산화제의 역할을 하는 폴리페놀과 플라보노이드 햠랑을 측정한 결과, 화산송이가 첨가된 발 효액에서 다소 감소되는 경향을 보였다(Table 1). 이는 천 연 소재 외에 화산송이가 첨가되어 폴리페놀과 플라보노 이드 함량이 감소된 결과로 생각된다.

항산화 활성 측정에 이용되고 있는 대표적인 radical인 $\mathrm{DPPH}$ 는 짙은 자색을 띄는 비교적 안정한 free radical로서 항산화제, 방향족 아민류 등에 의해 환원되어 색이 탈색 되는 것을 이용하여 항산화 물질을 검색하는데 이용되고

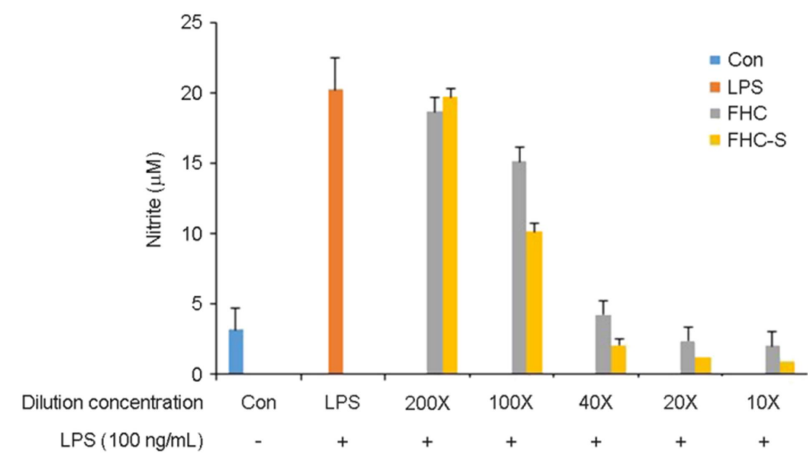

Fig. 4. Effect of fermented Houttuynia cordata (FHC) and fermented Houttuynia cordata-scoria (FHC-S) on NO production in BV-2 cells. FHC and FHC-S was treated with various concentrations in BV-2 cells for $24 \mathrm{~h}$. Values are expressed as the mean $\pm \mathrm{SD}(\mathrm{n}=3)$ of determinations made in triplicate experiments. Dilution concentration: $10 \times, 20 \times, 40 \times, 100 \times, 200 \times$

있다. 또한, ABTS+· 소거활성은 청록색으로 탈색된 free radical의 제거 정도를 흡광도 값으로 나타내어 $\mathrm{ABTS}+$ ·의 소거 활성능을 측정할 수 있고 탈색 반응이 1 분 안에 종 료되어 단시간에 측정 가능하다. 어성초 및 화산송이 복 합 발효액의 $\mathrm{DPPH}$ 와 $\mathrm{ABTS}$ 라디칼 소거능은 폴리페놀 및 플라보노이드 함량의 경향과 달리 화산송이를 첨가하 여 발효하였을 경우 소거활성이 증가되는 것을 확인하였 다(Fig. 2). 이는 화산송이 자체의 항산화 효능에 의해 어성 초 추출물과의 시너지 효과를 보인 것으로 생각된다.

LPS는 그람 음성 세균의 세포벽 물질이다. 단구세포 또 는 대식세포는 미량의 LPS에 의해 활성화되고 다양한 사 이토카인, 아라키돈산 대사산물, 활성산소, $\mathrm{NO}$ 등을 생산, 방출한다(Gross and Wolin, 1995; Stuehr, 1999). NO는 정상적 인 생리 상태에서 혈관의 항상성, apoptosis 유도 작용 등 중요한 생리적인 기능을 매개하지만 다량의 $\mathrm{NO}$ 는 정상 세포를 죽이고 염증을 유도하여 급성 또는 만성 염증질 환의 원인이 되는 물질로 작용하게 된다(Halliwell, 1992). 따라서, 효과적인 NO 분비조절은 급성 또는 만성 염증질 환의 치료방법으로 알려져 있으며 이에 대한 연구가 활발 히 진행되고 있다. 이에 어성초 및 화산송이 복합 발효액 이 $\mathrm{NO}$ 의 생성을 저해할 수 있는지를 알아본 결과 Fig. 4 와 같이 나타났다. $\mathrm{NO}$ 생성저해 효과를 측정하기 전에 어 성초 및 화산송이 복합 발효액이 세포에 독성을 나타내는 지를 MTT assay를 이용하여 측정하였을 때, FHC-S(어성초 -화산송이 복합 발효액) 10 배 희석액에서 세포독성을 확 인하였다(Fig. 3). 이는 화산송이 첨가로 인한 결과로 사료 
된다. LPS만 처리한 군에서는 $\mathrm{NO}$ 가 약 $19.9 \mu \mathrm{M}$ 로 처리하 지 않은 군보다 약 5 배 이상의 $\mathrm{NO}$ 를 생성하였고 여기에 $\mathrm{FHC}$ (어성초 발효액) 그리고 $\mathrm{FHC}-\mathrm{S}$ (어성초-화산송이 복합 발효액)를 처리한 군의 경우 희석농도에 따라 $\mathrm{NO}$ 생성이 감소되는 것을 확인하였고, $\mathrm{FHC}-\mathrm{S}$ (어성초-화산송이 복합 발효액) 처리한 군에서 $\mathrm{NO}$ 생성저해 효과가 더 우수하게 나타나는 것을 확인하였다(Fig. 4). 이는 라디칼 소거능이 FHC-S(어성초-화산송이 복합 발효액)가 더 우수하게 나 타난 결과와 일치한 것을 보였다.

본 연구에서 사용된 $\mathrm{FHC}$ (어성초 발효액) 보다는 FHC-S (어성초-화산송이 복합 발효액)가 화산송이가 혼합되면서 시너지 효과를 나타내는 것으로 생각되며 이러한 화산송 이 첨가 발효액은 염증성 질환의 예방 및 치료용 기능성 소재로 활용될 수 있으리라 본다.

\section{ACKNOWLEDGEMENTS}

This research was supported by the Ministry of Trade, Industry \& Energy (MOTIE), Korea Institute for Advancement of Technology (KIAT) through the Encouragement Program for The Industries of Economic Cooperation Region.

\section{CONFLICT OF INTEREST}

The authors have no conflicts of interest to disclose.

\section{REFERENCES}

Aischer RG, Hess JL. Antioxidants in higher plants. CRC Press, Boca Raton, 1993. 1-17.

Bae EA, Han MJ, Kim EJ, Kim DH. Transformation of ginseng saponins to ginsenoside $\mathrm{Rh} 2$ by acids and human intestinal bacteria and biological activities of their transformations. Archives of Pharmacal Research. 2004. 27: 61-67.

Bors W, Saran M. Radical scavenging by flavonoid antioxidants. Free Radical Research Communications. 1987. 2: 289-294.

Bouayed J, Bohn T. Exogenous antioxidants-Double-edged swords in cellular redox state: Health beneficial effects at physiologic doses versus deleterious effects at high doses. Oxidative Medicine and Cellular Longevity. 2010. 3: 228-237.

Chen $\mathrm{L}, \mathrm{Hu} J \mathrm{U}$, Wang SQ. The role of antioxdants in photoprotection: A critical review. Journal of the American Academy of Dermatology. 2012. 67: 1013-1024.

Chung CK, Ham SS, Lee SY, Oh DH, Choi SY, Kang IJ, Nam SM. Effects of Houttuynia cordata ethanol extracts on serum lipids and antioxidant enzymes in rats fed high fat diet. Journal of the Korean Society of Food Science and Nutrition. 1999. 28 205-211.

Decker EA, Crum AD, Calvert JT. Differences in the antioxidant mechanism of carmosine in the presence of copper and iron. Journal of Agricultural and Food Chemistry. 1992. 40: 756 -759 .

Folin O, Denis W. On phosphotungstic-phosphomolybdic compounds as color reagents. The Journal of Biological Chemistry. 1912. 12: 239-249.

Gerriten ME. Flavonoids inhibit cytokine-induced endothelial cell adhesion protein gene expression. American Journal of Pathology. 1995. 147: 278-292.

Gross SS, Wolin MS. Nitric oxide: Pathophysiological mechanisms. Annual Review of Physiology. 1995. 57: 737-769.

Halliwell B. Reactive oxygen species and the central nervous system. Journal of Neurochemistry. 1992. 59: 1609-1623.

Hong ND, Kim NJ. Quality control of herbal medicines. Shinil Books. 2004.

Jang SM, Noh SH, Park SD. Herbal resource plant. Hakmoon Press. 1999.

Jeong HR, Kwak JH, Kim JH, Choi GN, Jeong CH, Heo HJ. Antioxidant and neuronal cell protective effects of an extract of Houttuynia cordata Thunb (a culinary herb). Korean Journal of Food Preservation. 2010. 17: 720-726.

Lee YJ, Shin DH, Chang YS, Shin JH. Antioxidative effect of some edible plant solvent extracts with various synergists. Korean Journal of Food Science and Technology. 1993. 25: 683-688.

Nieva, Moreno MI, Isla MI, Sampietro AR, Vattuone MA. Comparison of the free radical-scavenging activity of propolis from several regions of Argentina. Journal of Ethnopharmacology. 2000. 71: 109-114.

Re R, Pellegrini N, Proteggente A, Pannala A, Yang M, RiceEvans C. Antioxidant activity applying an improved ABTS radical cation decolorization assay. Free Radical Biology and Medicine. 1999. 26: 1231-1237.

Sato M, Ramarathnam N, Suzuki Y, Ohkubo T, Takeuchi M, Ochi H. Varietal differences in the phenolic content and superoxide radical scavenging potential of wines from different sources Journal of Agricultural and Food Chemistry. 1996. 44: 37-41.

Song JH, Kim MJ, Kwon HD, Park IH. Antimicrobial activity of fractional extracts from Houttuynia cordata root. Journal of the Korean Society of Food Science and Nutrition. 2003. 32 1053-1058. 
Stuehr DJ. Mammalian nitric oxide synthases. Biochimica et Biophysica Acta. 1999. 1411: 217-230.

Suolinna EM, Buchsbaum RN, Racker E. The effect of flavonoids on aerobic glycolysis and growth of tumor cells. Cancer Research. 1975. 35: 1865-1872.

Tanaka H, Dinenno FA, Monahan KD, Clevenger CM, DeSouza

CA, Seals DR. Aging, habitual exercise, and dynamic arterial compliance. Circulation. 2000. 102: 1270-1275.

Wiseman H. Dietary influences on membrane function: impotent in protection against oxidative damage and disease. The Journal of Nutritional Biochemistry. 1996. 7: 2-15.

https://doi.org/10.15616/BSL.2017.23.4.355

Cite this article as: SG Lee, S Kang, KY Lee, KL Park, H Kang. Anti-inflammatory Effects of Fermented Houttuynia cordata Thunb and Scoria Mixture Extract. Biomedical Science Letters. 2017. 23: 355-361. 